Research article

\title{
Diversity and distribution of Litsea in Chikkamagaluru, Karnataka
}

\author{
S. G. Srinivas and Y. L. Krishnamurthy* \\ Dept. of P.G Studies and Research in Applied Botany, Kuvempu University, Jnanasahyadri, \\ Shankaraghatta-577451, Shivamogga, Karnataka, India \\ *Corresponding Author: murthy_ylk@yahoo.co.in \\ [Accepted: 29 October 2016]
}

\begin{abstract}
The study gives a report on the diversity of Litsea (Lauraceae) occur in Chikkamagaluru district of Karnataka, India. Study was conducted in two habitats of Kemmannugundi and Mullayyanagiri regions. Extensive field surveys were conducted for survey of the species by laying six belt transects of $250 \times 4 \mathrm{~m}$ size. The data indicated that four species of Litsea occurred in the study sites; namely, Litsea floribunda, Litsea stocksii, Litsea glabrata and Litsea mysorensis. L. floribunda showed higher density when compared with other species, all the four species distributed frequently in Kemmannugundi whereas; in Mullayyanagiri only L. floribunda species is present. These trees commonly associated with other tree species are Cinnamomum verum, Neolitsea cassia, Maesa indica, Memecylon malabaricum and Syzizium cumini.
\end{abstract}

Keywords: Associated species - Kemmannugundi - Lauraceae - Mullayyanagiri - Western Ghats.

[Cite as: Srinivas SG \& Krishnamurthy YL (2016) Diversity and distribution of Litsea in Chikkamagaluru, Karnataka. Tropical Plant Research 3(3): 564-568]

\section{INTRODUCTION}

The genus Litsea consists of about 400 species which is largest genus in the family Lauraceae distributed in tropical and subtropical Asia, Australia, New Zealand, North America and subtropical South America (Chaing et al. 2012). In India about 45 species are distributed in evergreen and semi evergreen forests of the Western Ghats (Bhuniya et al. 2010), 12 species are also found in Meghalaya, Manipur, Assam and Sikkim. Among 45 species 40 of which are endemic to peninsular India, 11 species are found in Karnataka (Saldanha 1996).

The Litsea trees are evergreen dioecious with alternate or whorled leaves, inflorescence is pedunculate axillary umbellate or corymbose racemes. Bracts are present, 4-6 in numbers perianth tube companulate, anthers four celled. Ovary free or coverved by perianth, style curved, stigma dilated, fruit ovoid or globose (Gamble \& Fischer 1998).

Leaves and barks of Litsea stocksii and L. glutinosa are used as medicines. Essential oils like citral, lauric acid and oleic acid extracted are used commercially for the preparation of insecticides, perfumes, flavours and colognes. Oil extracted from Litsea cubeba is a good competitor of Chinese lemon oil due to its low cost of production and easy method of cultivation of the species. Decoction of different parts of the plant used to cure burns, sprains, cough, bronchitis and paralysis (Bhuniya et al. 2009).

The taxonomy of the family Lauraceae is still not settled compare to other families. It is poorly understood due to its great diversity, inadequate morphological characters and lack of investment in taxonomic work. Litsea is a very interesting tree species in Western Ghats of India occur in evergreen and semi evergreen forests, information on its diversity, distribution and genetic relatedness within populations are not fully explored. Hence in this present study we focussed to study the diversity and distribution of Litsea species in Chikkamagaluru district, Karnataka.

\section{MATERIALS AND METHODS}

Study area

The study area covers Kemmannugundi, Mullayyanagiri in Chikkamagaluru district situated between $12^{\circ} 54^{\prime}$ to $13^{\circ} 53^{\prime} \mathrm{N}$ and $75^{\circ} 04^{\prime}$ to $76^{\circ} 21^{\prime} \mathrm{E}$ in the Western Ghats regions of Karnataka (Fig. 1). The sampling sites have 
rich forest vegetation such as evergreen and semi evergreen forests, the wide range of ecological conditions and altitudinal variation resulted in diverse vegetation in study area. Mullayyanagiri is the highest elevated region in Karnataka. In Kemmannugundi, Mullayyanagiri region the temperature varies between $10^{\circ}$ to $32^{\circ} \mathrm{C}$ across the different months of the year.

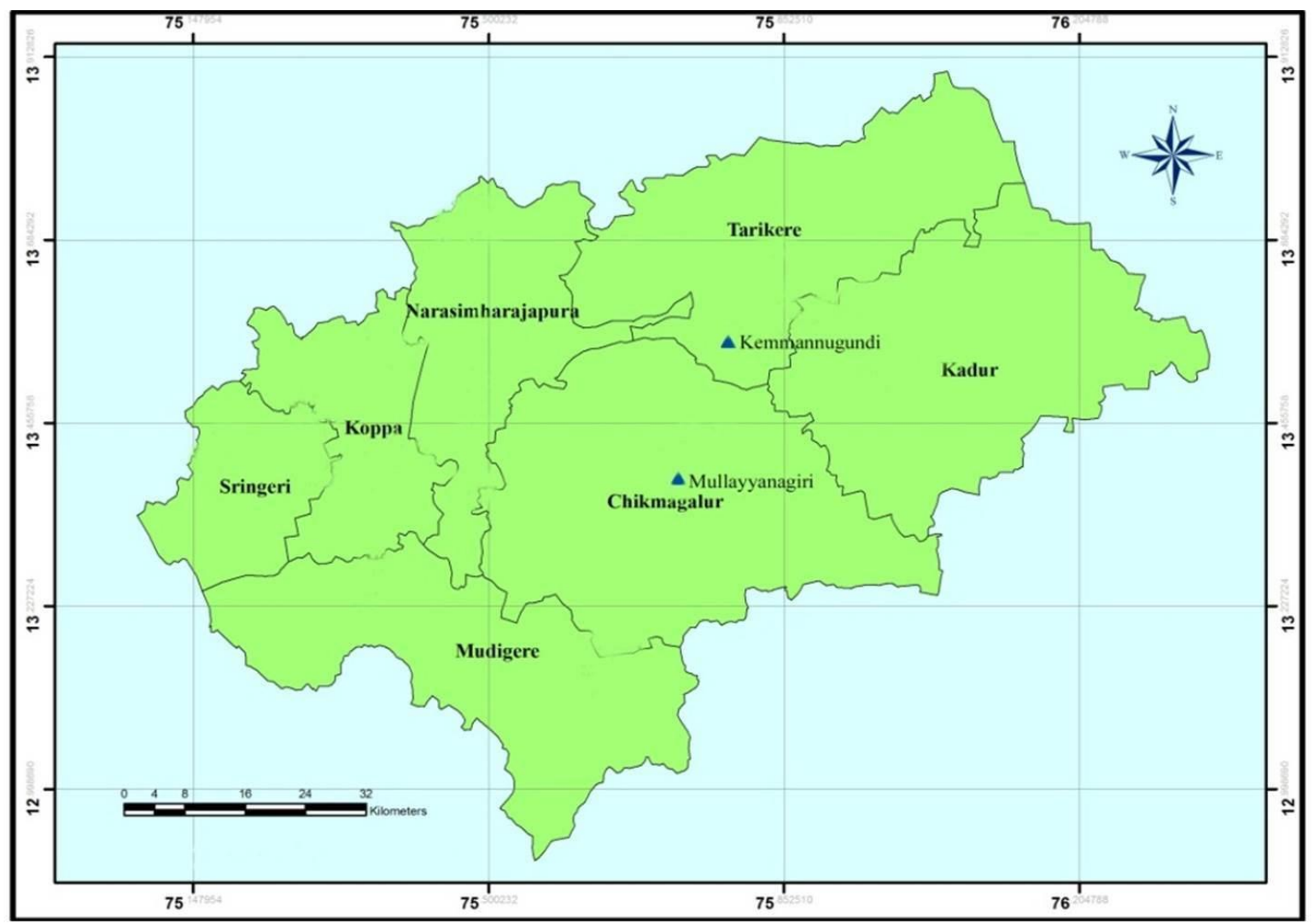

Figure 1. Map showing sampling sites in Chikkamagaluru District, Karnataka.

\section{Tree sampling and Data analysis}

Extensive field surveys carried out throughout the year to know the diversity, distribution and phenology of the Litsea species. Stratified random sampling method is used to collect the tree data, three belt transects of $250 \times 4 \mathrm{~m}$ was laid in each study sites and girth was measured at breast height using a girth tape. Species density, frequency, abundance, importance value index and basal area of plant were calculated by following Mishra (1968), Mueller-Dambois \& Ellenberg (1974). The importance value index was calculated by summing of relative density, frequency and relative dominance. Species diversity index was calculated by Shannon Wiener index (1963); the species dominance index was calculated by using Simpson (1949).

\section{RESULTS AND DISCUSSION}

The four species of Litsea occurred in the two study sites; namely, Litsea floribunda, Litsea stocksii, Litsea glabrata and Litsea mysorensis (Fig. 2). These four species collected from the study sites, identified through some morphological characters using standard floras and herbarium samples were prepared. L. floribunda is present in Kemmannugundi and Mullayyanagiri, but the L. stocksii, L. glabrata, L. mysorensis only present in Kemmannugundi region absent in Mullayyanagiri (Table 1).

The results showed that L. floribunda frequently present in all transects, the frequency of L. glabrata is 0.67 , L. mysorensis 0.33 , L. stocksii 1.0 . The L. floribunda showed highest density 46.67 and 33.67 it covers a basal area of $1904.79 \mathrm{~m}^{2} \cdot \mathrm{ha}^{-1}$ and $885.27 \mathrm{~m}^{2} \cdot \mathrm{ha}^{-1}$ (Table 1) in Mullayyanagiri and Kemmannugundi respectively, $L$. mysorensis showed lesser density and basal area compare to all the species. Abundance and frequency (A/F) ratio of all the Litsea species in the study sites is $>0.05$, it showed a clumped or contagious pattern of distribution this is because it is a dioecious tree, clumping of individuals of the same species is often clearly related to gap formation and dispersal, pollination mechanism of the species. Upadhaya et al. (2003) investigated on the same family members Cinnamomum and Neolitsea it also showed clumped pattern of distribution. 

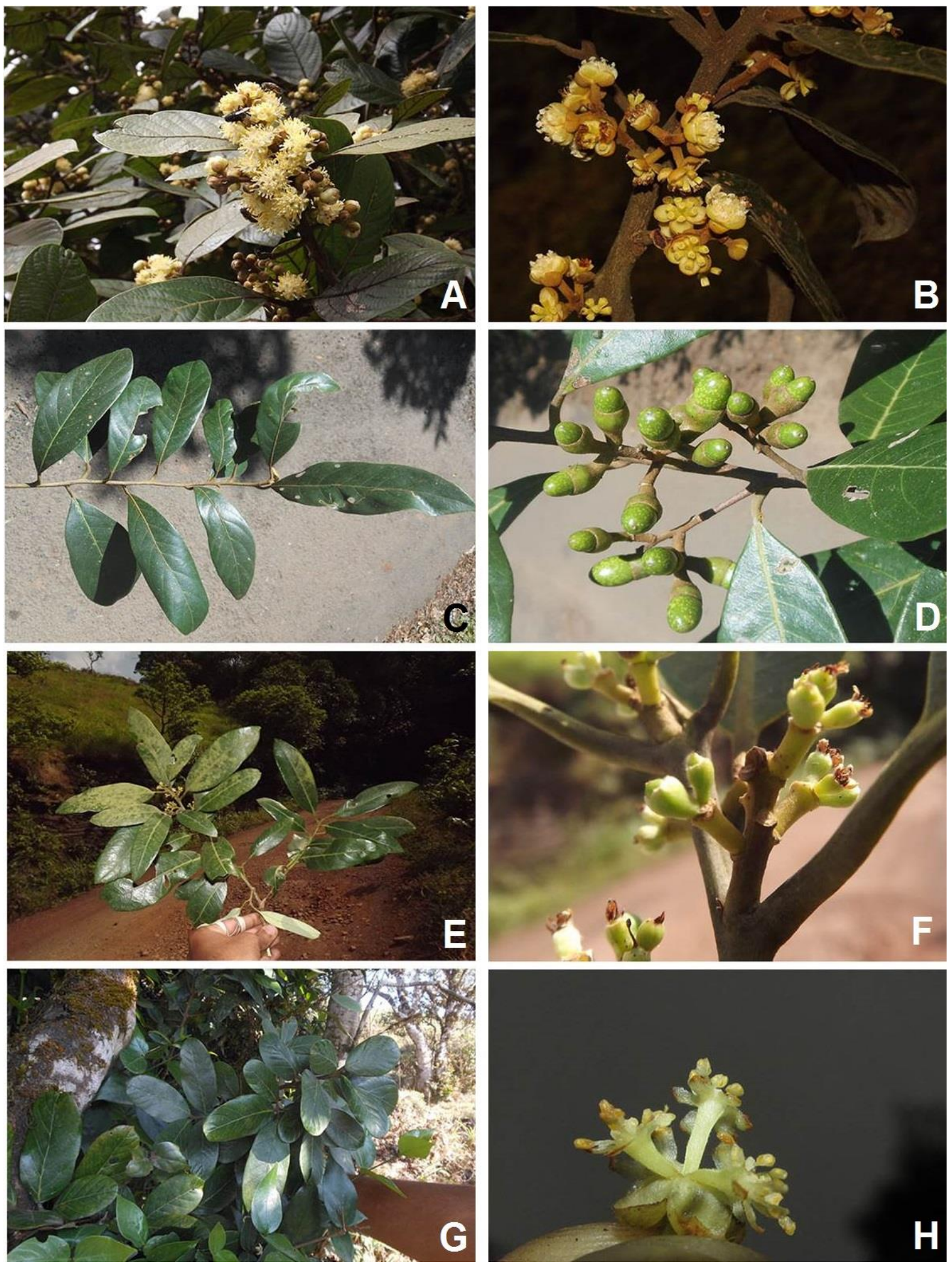

Figure 2. Litsea species in Chikkamagaluru district, Karnataka: A-B, Litsea floribunda; C-D, Litsea stocksii; E-F, Litsea mysorensis; G-H, Litsea glabrata.

A total of 15 associated species belongs to 10 families were recorded in both Kemmannugundi and Mullayyanagiri study sites (Table 2). Five species belongs to family Lauraceae, this is because of preference of same environmental factors from the genera. Callicarpa, Cinnamomum, Cryptocarya, Neolitsea and Syzygium species are frequently distributed in all the transects of Kemmannugundi. Cinnamomum showed high density (21.33) per transect in Mullayyanagiri whereas Memecylon, Ochlandra, Psychotria showed low density (0.33) www.tropicalplantresearch.com 
in both the study sites (Table 2). Actinodaphne, Cryptocarya, Macaranga and Neolitsea cassia only present in Kemmannugundi absent in Mullayyanagiri region.

Table 1. Frequency (Fre), density per transect (Den), abundance (Abun), IVI, A/F ratio of Litsea spp.

\begin{tabular}{crrrrrrrrr}
\hline Species & Fre & Den & Abun & RF & RD & RA & IVI & A/F & Basal area $\mathbf{~ m}^{2} / \mathbf{h a}$ \\
\hline Kemmannugundi & & & & & & & & & \\
Litsea floribunda & 1 & 33.67 & 33.67 & 7.32 & 37.14 & 29.93 & 74.39 & 4.6 & 885.27 \\
Litsea glabrata & 0.67 & 2 & 3 & 4.88 & 2.21 & 2.67 & 9.76 & 0.61 & 1.77 \\
Litsea mysorensis & 0.33 & 1 & 3 & 2.44 & 1.1 & 2.67 & 6.21 & 1.23 & 0.48 \\
Litsea stocksii & 1 & 7 & 7 & 7.32 & 7.72 & 6.22 & 21.26 & 0.96 & 39.48 \\
Mullayyanagiri & & & & & & & & & \\
$\quad$ Litsea floribunda & 1 & 47.67 & 47.67 & 10 & 50 & 44.9 & 104.9 & 4.77 & 1904.79 \\
\hline
\end{tabular}

Table 2. Frequency (Fre), density per transect (Den), abundance (Abun), IVI, A/F ratio of the major associated species.

\begin{tabular}{|c|c|c|c|c|c|c|c|c|c|c|c|c|c|c|c|c|}
\hline \multirow{2}{*}{ Species } & \multirow[b]{2}{*}{ Fre } & \multirow[b]{2}{*}{ Den } & \multirow[b]{2}{*}{ Abun } & \multicolumn{5}{|c|}{ Kemmannugundi } & \multicolumn{8}{|c|}{ Mullayyanagiri } \\
\hline & & & & RF & RD & $\mathbf{R A}$ & IVI & $\mathbf{A} / \mathbf{F}$ & Fre & Den & Abun & RF & RD & $\mathbf{R A}$ & IVI & $\mathbf{A} / \mathbf{F}$ \\
\hline Actinodaphne sp. & 0.33 & 1.67 & 5 & 2.44 & 1.84 & $\overline{4.44}$ & 8.72 & 2.05 & - & & - & - & - & 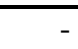 & & \\
\hline Callicarpa tomentosa & 1 & 2.67 & 2.67 & 7.32 & 2.94 & 2.37 & 12.63 & 0.36 & 1 & 1.67 & 1.67 & 10 & 1.75 & 1.57 & 13.32 & 0.17 \\
\hline Cinnamomum verum & 1 & 11 & 11 & 7.32 & 12.13 & 9.78 & 29.23 & 1.5 & 1 & 21.33 & 21.33 & 10 & 22.3 & 20 & 52.3 & 2.13 \\
\hline Cryptocarya sp. & 1 & 4.67 & 4.67 & 7.32 & 5.15 & 4.15 & 16.62 & 0.64 & - & - & - & - & - & - & - & - \\
\hline Glochidion sp. & 0.67 & 3.67 & 5.5 & 4.88 & 4.04 & 4.89 & 13.81 & 1.13 & 0.67 & 3 & 4.5 & 6.67 & 3.15 & 4.24 & 14.06 & 0.68 \\
\hline Macaranga peltata & 0.67 & 1.67 & 2.5 & 4.88 & 1.84 & 2.22 & 8.94 & 0.51 & - & - & - & - & - & - & - & - \\
\hline Maesa indica & 0.67 & 4.33 & 6.5 & 4.88 & 4.78 & 5.78 & 15.44 & 1.33 & 1 & 3.67 & 3.67 & 10 & 3.85 & 3.45 & 17.3 & 0.37 \\
\hline Memecylon malabaricum & 0.33 & 0.33 & 1 & 2.44 & 0.37 & 0.89 & 3.7 & 0.41 & 0.33 & 0.33 & 1 & 3.33 & 0.35 & 0.94 & 4.62 & 0.3 \\
\hline Neolitsea cassia & 1 & 5 & 5 & 7.32 & 5.52 & 4.44 & 17.28 & 0.68 & 1 & 4.33 & 4.33 & 10 & 4.55 & 4.08 & 18.63 & 0.43 \\
\hline Neolitsea zeylanica & 0.67 & 2.33 & 3.5 & 4.88 & 2.57 & 3.11 & 10.56 & 0.72 & - & - & - & - & - & - & - & - \\
\hline Nothapodytes foetida & 0.33 & 1.33 & 4 & 2.44 & 1.47 & 3.56 & 7.47 & 1.64 & 0.67 & 2.33 & 3.5 & 6.67 & 2.45 & 3.3 & 12.42 & 0.53 \\
\hline Ochlandra travancorica & 0.33 & 0.33 & 1 & 2.44 & 0.37 & 0.89 & 3.7 & 0.41 & 0.33 & 0.33 & 1 & 3.33 & 0.35 & 0.94 & 4.62 & 0.3 \\
\hline Psychotria nigra & 0.33 & 0.33 & 1 & 2.44 & 0.37 & 0.89 & 3.7 & 0.41 & 0.33 & 0.33 & 1 & 3.33 & 0.35 & 0.94 & 4.62 & 0.3 \\
\hline Syzygium cumini & 1 & 4 & 4 & 7.32 & 4.41 & 3.56 & 15.29 & 0.55 & 0.67 & 4.67 & 7 & 6.67 & 4.9 & 6.59 & 18.16 & 1.05 \\
\hline Vernonia arborea & 0.33 & 1 & 3 & 2.44 & 1.1 & 2.67 & 6.21 & 1.23 & 0.33 & 0.33 & 1 & 3.33 & 0.35 & 0.94 & 4.62 & 0.3 \\
\hline
\end{tabular}

Shanon index is a diversity index taking into account of number of individuals as well as number of taxa. The Shanon and Simpson index of Kemmannugudi is 2.32, 0.82 respectively and 1.65, 0.69 in Mullayyanagiri respectively (Fig. 3). According to Shanon and Simpson indices Kemmannugundi has highest species richness area compare to the Mullayyanagiri region. The Shanon index of the Kemmannugundi region is lower (2.32) compare to Sulimudi forests of Western Ghats, Kerala (2.64) (Magesh \& Menon 2011) and Simpson value higher (0.82) compare to Vagamon region (0.36) (Brilliant et al. 2012).

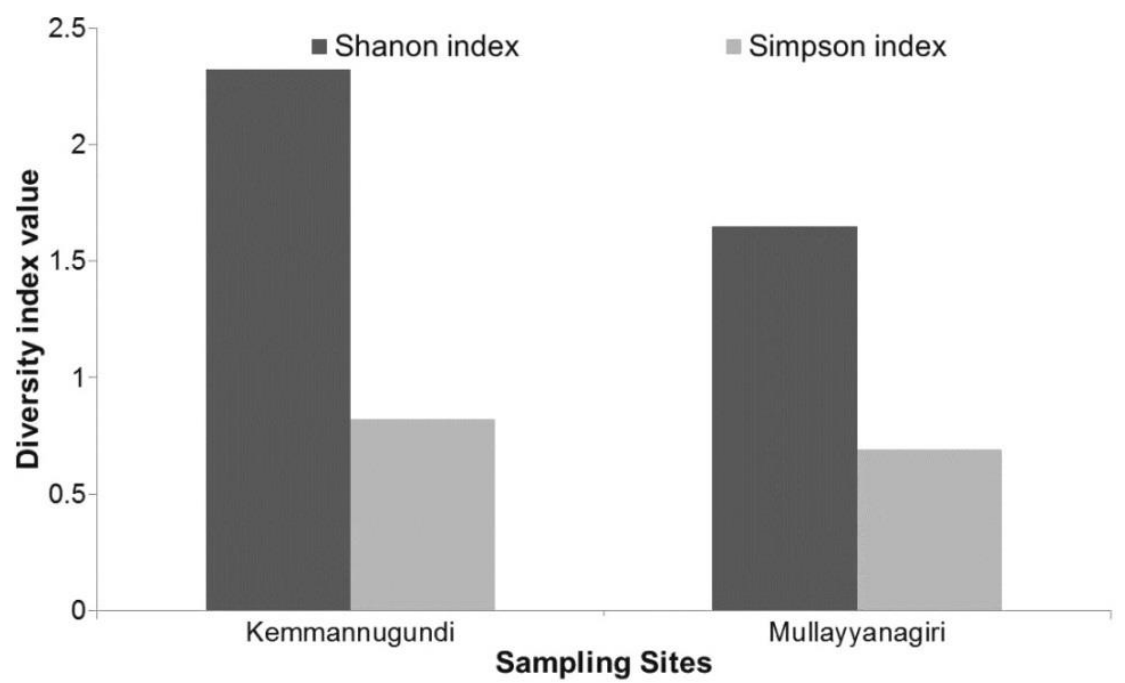

Figure 3. Shanon and Simpson diversity index in Kemmannugundi and Mullayyanagiri.

\section{CONCLUSION}


This study revealed that the two study sites harboured four Litsea species and Litsea floribunda showed good species richness. Litsea stocksii, Litsea glabrata and Litsea mysorensis showed low species richness in Kemmannugundi whereas these species absent in Mullayyanagiri. A total of 15 associated species belongs to 10 families were recorded; Laural members are the dominant associated species in both the study sites.

\section{ACKNOWLEDGEMENTS}

The authors are thankful to the Department of Science and Technology (DST) New Delhi, for providing financial assistance as an Inspire Fellowship (IF140097) to Srinivas SG and authors also acknowledge thanks to Kuvempu University to providing research facilities. The author also acknowledges special thanks to Shravan Kumar S., Avinash K.S., Ashwini H.S., for their help in field collections in the studies.

\section{REFERENCES}

Bhuniya T, Singh P \& Mukherjee SK (2009) Distribution of the genus Litsea Lam. (Lauraceae) in India with special reference to rare and endemic species. Phytotaxonomy 9: 116-121.

Bhuniya T, Singh P \& Mukherjee SK (2010) An account of the species of Litsea Lam. (Lauraceae) endemic to India. Bangladesh Journal of Plant Taxon 17: 183-191.

Brilliant R, Varghese VM, Paul J \& Pradeepkumar AP (2012) Vegetation analysis of montane forest of Western Ghats with special emphasis on RET species. International journal of Biodiversity and Conservation 4: 652664.

Chaing YC, Huei CS, Min CH, Li PJ \& Hsiang HK (2012) Characterization of microsatellite loci from Litsea hypophaea, a tree endemic to Taiwan. American Journal of Botany 99(6): e251-e254.

Gamble JS \& Fischer CEC (1998) Flora of Presidency of Madras, Vol. 1-3. Adlard and Son Limited, 21, Hart street, WC.

Magesh G \& Menon ARR (2011) Vegetation status, species diversity and endemism of Sulimudi forests in southern Western Ghats of Kerala, India. The Indian Forester 2: 304-311.

Mishra R (1968) Ecology work book. Oxford and IBH publishing company Calcutta India.

Mueller DD \& Ellenberg H (1974) Aims and methods of vegetation ecology. John Wiley and Sons New York USA.

Saldanha CJ (1996) Flora of Karnataka, Vol. 1-4. Oxford and IBH publishing Ltd, New Delhi.

Shanon CE \& Weiner W (1963) The Mathematical theory of communication. University of Illinois press Urbana.

Simpson EH (1949) Measurement of diversity. Nature 163: 688.

Upadhaya K, Pandey HN, Law PS \& Tripathi RS (2003) Tree diversity in sacred grooves of the Jaintia hills in Meghalaya, Northeast India. Biodiversity and Conservations 12: 583-597. 